\title{
Manure and sorbent fertilisers increase on-going nutrient availability relative to conventional fertilisers
}

\author{
M.R. Redding *, R. Lewis, T. Kearton, O. Smith \\ AgriScience Queensland, Department of Agriculture and Fisheries, P.O. Box 102, Toowoomba, Queensland, Australia
}

\section{H I G H L I G H T S}

- Field and glasshouse studies to investigate efficient in-season nutrient supply.

- Sorbent additions (hydrotalcite; HT) tended to defer P availability (2 soils).

- Spent litter derived nutrient (manure; $\mathrm{SL}$ ) deferred $\mathrm{P}$ availability in some soils.

- Sorbent additions (bentonite, HT) increased residual nutrient $(\mathrm{N}, \mathrm{P}$ respectively).

- Manures and ion-exchangers may match Conv $\mathrm{N}$ and $\mathrm{P}$ sources with lower losses.

\section{G R A P H I C A L A B S T R A C T}

Sorbents retain fertiliser phosphorus and nitrogen in the soil

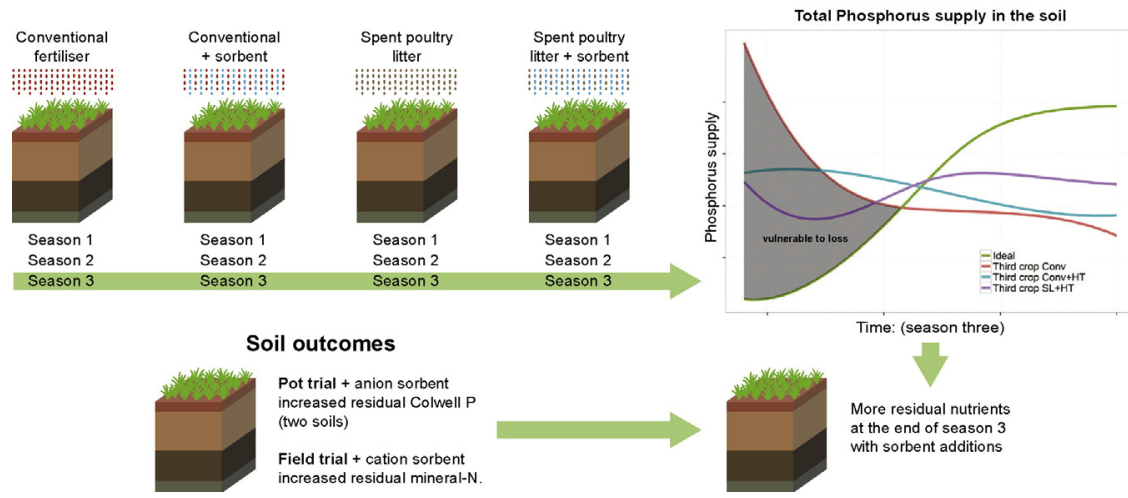

\begin{abstract}
A B S T R A C T
The key to better nutrient efficiency is to simultaneously improve uptake and decrease losses. This study sought to achieve this balance using sorbent additions and manure nutrients (spent poultry litter; SL) compared with results obtained using conventional sources (Conv; urea nitrogen, $\mathrm{N}$; and phosphate-phosphorus; P). Two experiments were conducted. Firstly, a phosphorus pot trial involving two soils (sandy and clay) based on a factorial design (Digitaria eriantha/Pennisetum clandestinum). Subsequently, a factorial $\mathrm{N}$ and $\mathrm{P}$ field trial was conducted on the clay soil (D. eriantha/Lolium rigidum). In the pot trial, sorbent additions (26.2 $\mathrm{g}$ of hydrotalcite [HT] $\mathrm{g} \mathrm{P}^{-1}$ ) to the Conv treatment deferred P availability (both soils) as did SL in the sandy soil. In this soil, P delivery by the Conv treatments declined rapidly, and began to fall behind the HT and SL treatments. Addition of HT increased post-trial Colwell P. In the field trial low HT-rates ( 3.75 and $7.5 \mathrm{~g}$ of $\mathrm{HT} \mathrm{g} \mathrm{P}^{-1}$ ) plus bentonite, allowed dry matter production and nutrient uptake to match that of Conv treatments, and increased residual mineral$\mathrm{N}$. The SL treatments performed similarly to (or better than) Conv treatments regarding nutrient uptake. With successive application, HT forms may provide better supply profiles than Conv treatments. Our findings, combined with previous studies, suggest it is possible to use manures and ion-exchangers to match conventional $\mathrm{N}$ and P source productivity with lower risk of nutrient losses.
\end{abstract}

Crown Copyright @ 2016 Published by Elsevier B.V. All rights reserved.

\footnotetext{
* Corresponding author.

E-mail address: matthew.redding@daff.qld.gov.au (M.R. Redding).
} 


\section{Introduction}

Despite decades of agricultural research, applications of conventional fertiliser products, such as urea and superphosphate, result in only 40 to $60 \%$ plant uptake of the target nutrients (Bolland and Gilkes, 1998; David and Gentry, 2000; Drinkwater and Snapp, 2007; Galloway and Cowling, 2002; Van der Molen et al., 1998). For P and N, losses take different forms via different paths. The residual value of previously applied conventional phosphorus fertilisers is indicated to decline with time after application (Bolland and Gilkes, 1998). This is due to the rapid conversion of soluble forms to more stable less soluble forms. In contrast, where high yields are sought without regard to nitrogen fertiliser efficiency, the result can be the contamination of adjacent environments (e.g. Di and Cameron, 2002; Perego et al., 2012).

This presents a severe problem, given that the productivity of agricultural land will be required to rapidly increase to meet international demands. For example it is foreseeable that China will require 30 to $50 \%$ more food to meet demand in the next two decades (Zhang et al., 2013). However, the problem is not restricted to China. There is both a requirement and an economic opportunity for food exporting nations to increase productivity.

To date, nations have achieved improved crop production at the expense of increasingly leaky fertiliser practices (Drinkwater and Snapp, 2007; Zhang et al., 2011). Decreasing the losses associated with crop fertiliser delivery is becoming a substantial community focus. For example in Australia, where intensive crop production may occur adjacent to sensitive environments (e.g. The Great Barrier Reef), community concern has increased after scientists have suggested causal links between water quality and reef health (Queensland Government, 2015). Solutions to enable efficient, yet high-yield, agriculture are being sought.

It is know that precise application of fertiliser nutrients just in time to meet a maturing crop's demand can substantially decrease system losses and inefficiency. By managing $\mathrm{N}$ fertiliser in a manner that ensured non-limiting $\mathrm{N}$ supply with minimum excess (and minimum losses) through in-season root zone N management. Chen et al. (2006, 2010) were able to almost double maize yields with no increase in fertiliser use (Zhang et al., 2011). In this management, total fertiliser $\mathrm{N}$ additions are divided into sub-applications that are applied throughout the growing season (Cui et al., 2010). This practice would only suit agricultural production systems where it is feasible to access the crop for additional fertiliser applications during the growing cycle. In many agricultural systems this approach may result in crop disturbance or excessive fertiliser application costs. In these circumstances, other options that are able to efficiently supply nutrients to meet growth requirements may enable the same benefits to be achieved.

Conventional fertiliser practice emphasises the uptake of inorganic nutrient forms. However, it is known that some organic nutrients are available to plants (Paungfoo-Lonhienne et al., 2008, 2012; Schmidt et al., 2013). The relative importance of organic nutrient uptake (compared to inorganic nutrient forms) remains unknown (Nasholm et al., 2009).

Models have been used to predict nutrient availabilities from manure or organic waste applications to soils in experimental crop management (e.g. composts and manures, Archontoulis et al., 2014; Beraud et al., 2005). However, no attempt appears to have been made to tie waste material nutrient release to in-season nutrient requirements of crops or pastures.

Innovation in fertiliser efficiency has a long history (e.g. Ellis, 1907), and a range of approaches have been taken to enhance the effectiveness of fertiliser materials, dominantly via controlled or slow release or via the application of nitrification or urease hydrolysis inhibitors (Halvorson et al., 2014; Timilsena et al., 2015). The nutrient delivering efficiency of these products tends to be higher than that of conventional fertilisers, due to their enhanced potential for in-season nutrient supply, and decreased potential for leaching, run-off, and gaseous nutrient losses (Dave et al., 1999; Trenkel, 2010). Another important advantage is a decrease in the damage to leaves and roots due to osmotic stress (Shaviv, 2001; Trenkel, 2010). While some of these approaches have demonstrated substantial agronomic or environmental advantages, they tend to be expensive ( 2 to 13 times the cost of equivalent masses of conventional fertiliser nutrient; Lammel, 2005).

Nitrogen transformation inhibitors (urease and nitrification inhibitors) may be less expensive than encapsulated fertiliser products, however, they tend to be temperature sensitive (breaking down as temperatures increase; Irigoyen et al., 2003; Ruser and Schulz, 2015), and there are health concerns regarding the application of some forms of inhibitors (hydroquinone; Trenkel, 2010). Even where there is no demonstrated health effect, observation of residues in agricultural products (e.g. Danaher and Jordan, 2013) can be a barrier to adoption of these technologies.

Ion exchange materials have been proposed as a means to tailor nutrient supply to meet plant demand without excessive nutrient availability and decreased leaching losses (Gillman and Noble, 2005; Gillman, 2011). The advantage of the ion-exchange mechanism in nutrient supply is that these materials will tend to buffer solution concentrations, potentially supplying further nutrient as the plant lowers solution concentrations in the rhizosphere. Materials investigated in this role include: hydrotalcite, an anion exchanger able to retain $\mathrm{P}$ and $\mathrm{N}$ as nitrate; and bentonite (Gillman, 2011; Redding, 2011) or zeolite (Li et al., 2013) which have an affinity for ammonium cations. Further studies have established that cation exchanger additions can decrease nitrogen leaching losses (Aghaalikhani et al., 2012; Ding et al., 2010; Gholamhoseini et al., 2013; Singh et al., 2010). This study seeks to further investigate this potential through the application of an anion exchanger for $\mathrm{P}$ delivery and a cation exchanger for $\mathrm{N}$ delivery.

One approach may be to utilise waste organic nutrient sources, not simply to match conventional fertiliser performance, but to provide a means of on-going nutrient mineralisation and release (Adeli et al., 2011; Kihanda et al., 2005; Smith et al., 1998). This may prove to be a means to re-couple the nutrient and carbon cycles, potentially resulting in less nutrient losses due to nutrient excesses (Drinkwater and Snapp, 2007). Conventional use of manures as fertilisers often do not achieve this end, as demonstrated by a range of studies into nutrient losses (e.g. Chardon et al., 1997; Rasouli et al., 2014; Smith et al., 2007). However, it is likely that continued seasonal applications of moderate quantities of manure nutrients will result in steadily increasing availability of nitrogen, phosphorus, and potassium with successive applications (BarTal et al., 2004).

Initial groundwork identifying potential key advantages of manure use is already in place. A meta-analysis of available data suggests that while manure applications to soil (without formulation) as fertilisers resulted in significantly greater organic carbon (OC) in soils, the yield effects of these two nutrient sources were comparable (Edmeades, 2003). Given a history of annual manure application, it is possible to reach a point where annual $\mathrm{N}$ and $\mathrm{P}$ made available in the rhizosphere is equal to the manure $\mathrm{N}$ and $\mathrm{P}$ applied (Helgason et al., 2007). One study achieved on-going nutrient release matching crop requirements within 9 years using cattle manure and composted cattle manure (Miller et al., 2009). Effectively these observations suggest that manure nutrient forms defer nutrient availability relative to conventional fertiliser forms. As the agricultural paradigm shifts to a need for precise and efficient nutrient supply with low environmental losses, can these manure characteristics offer an advantage?

This is the starting point for our research. We sought to identify if we could use two ion exchange materials and a manure nutrient source (spent poultry litter; the bedding material collected from a commercial production facility after the production of a batch of broiler chickens) to defer $\mathrm{N}$ and $\mathrm{P}$ availability relative to a conventional fertiliser. To this end we conducted glasshouse and field trials over multiple seasons, observing a considerable offset of availability of $P$ relative to the conventional source. 


\section{Materials and methods}

\subsection{Materials}

Two soils were selected for investigation in a glasshouse pot trial. Both were representative of the surface $0.01 \mathrm{~m}$ of the profile, but were of very different character. The sandy soil was collected from Warwick, $130 \mathrm{~km}$ south west of Brisbane, from the A horizon of a Natrustalf (Soil Survey Staff, 1998), and is classified as a Grey Sodosol soil in the Australian Soil Classification (Isbell, 2002). The red clay soil, classified as a Red Ferrosol in the Australian Soil Classification (Isbell, 2002), or an Alfisol (Soil Survey Staff, 1998), was collected from Toowoomba, $125 \mathrm{~km}$ west of Brisbane.

Approximately $1 \mathrm{t}$ of each soil was transported to the laboratory. Coarse rocks and plant matter was removed from the field moist soil using a mechanical agitator and suspended sieve ( $2 \mathrm{~mm}$ aperture, $1 \mathrm{~m}$ diameter). Each sieved soil was further homogenised via mixing using a shovel on a plastic tarpaulin. Soils were subject to progressive air drying during storage.

Sixty kilograms of litter was collected from a meat chicken production unit in south-east Queensland, 25 days after birds were introduced into the shed (Table 1). Hardwood shavings to a depth of $50 \mathrm{~mm}$ were transferred to the shed at the commencement of the production cycle as a part of routine management. The bulked litter sample was representative of the full depth of litter, and the range of environments within the shed (e.g. from below drinkers, and from the space between). The litter was immediately transported to a cold room, mixed thoroughly, stored at $4{ }^{\circ} \mathrm{C}$ until used, and ground to pass a $2 \mathrm{~mm}$ aperture sieve immediately before use.

The sodium bentonite and hydrotalcite were obtained as described by Redding (2011). The bentonite material was ground and sieved to 0.5 to $2 \mathrm{~mm}$ diameter for use in the studies. The hydrotalcite was dried and ground to pass a $100 \mu \mathrm{m}$ screen.

Soils, spent litter and bentonite were subjected to analysis for (Rayment and Lyons, 2010): pH (1:5 mass ratio of sample to water), total-nitrogen (Kjeldahl nitrogen, method 7 A1), $2 \mathrm{M} \mathrm{KCl} \mathrm{extractable}$ ammonium- $\mathrm{N}\left(\mathrm{NH}_{4}^{+}-\mathrm{N}\right)$ and nitrate + nitrite- $\mathrm{N}$ by steam distillation for the spent litter $\left(\mathrm{NO}_{3}^{-}+\mathrm{NO}_{2}^{-} \mathrm{N}\right.$; method 7A1) and via colourimetric analysis for the other materials (method 7C2b); Colwell-phosphorus (bicarbonate extractable phosphorus, method 9B2), total-potassium (aqua regia digest; method $17 \mathrm{C} 1$ ), soluble (1 M ammonium chloride extract, pH 7.0; method 15 A1) and exchangeable bases (leaching with alcohol and glycerol solutions to remove soluble cations followed by alcoholic $1 \mathrm{M}$ ammonium chloride extract, $\mathrm{pH} 8.5$; method 15C1), effective cation exchange capacity (ECEC, sum of exchangeable cations; method 15J1), total carbon (high frequency induction furnace, method 6B2), total-phosphorus (Crosland et al., 1995), and organic carbon (Walkley and Black, 1934). Spent litter phytate content was estimated

Table 1

Bentonite and spent litter characteristics, reported on an oven dry basis. Effective cation exchange capacity $=$ ECEC.

\begin{tabular}{llll}
\hline & Units & Spent poultry litter & Bentonite \\
\hline Total N & $\%$ & $3.08 \pm 0.12$ & $0.027 \pm 0.001$ \\
$\mathrm{NO}_{3}^{-}-\mathrm{N}$ & $\%$ & $0.045 \pm 0.01$ & - \\
$\mathrm{NH}_{4}^{+}-\mathrm{N}$ & $\%$ & $0.43 \pm 0.31$ & - \\
Total P & $\%$ & $1.93 \pm 0.11$ & $0.018 \pm 0.003$ \\
Phytate P & $\%$ & $1.14 \pm 0.07$ & - \\
Bicarbonate P & $\%$ & - & $0.0004 \pm 0.0002$ \\
Total K & $\%$ & $2.82 \pm 0.01$ & $0.07 \pm 0$ \\
Organic C & $\%$ & $26.9 \pm 1.0$ & $0.36 \pm 0.03$ \\
Total C & $\%$ & $27.6 \pm 1.2$ & $0.95 \pm 0.11$ \\
Exchangeable Ca & $\mathrm{cmol}(+) \mathrm{kg}^{-1}$ & $13.8 \pm 0.2$ & $15.4 \pm 0.6$ \\
Exchangeable Mg & $\mathrm{cmol}(+) \mathrm{kg}^{-1}$ & $9.41 \pm 0.08$ & $14.9 \pm 0.9$ \\
Exchangeable K & $\mathrm{cmol}(+) \mathrm{kg}^{-1}$ & $75.3 \pm 0.7$ & $1.52 \pm 0.04$ \\
Exchangeable $\mathrm{Na}$ & $\mathrm{cmol}(+) \mathrm{kg}^{-1}$ & $30.1 \pm 0.4$ & $50.7 \pm 0.8$ \\
ECEC & $\mathrm{cmol}(+) \mathrm{kg}^{-1}$ & - & $82.6 \pm 2.3$ \\
\hline
\end{tabular}

via acid extraction, exchange column separation, followed Inductively Coupled Plasma Atomic Emission Spectroscopy analysis (Latta and Eskin, 1980). Soil phosphorus buffering capacity was determined via a single point index (method 9I2b, Rayment and Lyons, 2010). Hydrotalcite characteristics were analysed and reported for a previous study (Redding, 2011).

\subsection{Pot trial}

A total of 48 pots ( $200 \mathrm{~mm}$ diameter) of each soil were prepared. Each contained $2.8 \mathrm{l}$ of soil: $5.5 \mathrm{~kg}$ for the sandy soil pots, and $3.1 \mathrm{~kg}$ for the red clay soil. The treatments applied corresponded to a range of $\mathrm{P}$ additions $\left(0,12,24,36,48\right.$, and $\left.60 \mathrm{mg} \mathrm{P}[\mathrm{kg} \text { soil }]^{-1}\right)$, in the form of analytical reagent grade $\mathrm{K}_{2} \mathrm{HPO}_{4}$ (Conv) or spent poultry litter (SL; duplicates of each nutrient source at each $P$ rate). Half the $P$ treated pots also received hydrotalcite (HT) at a rate of $26.2 \mathrm{~g}$ of hydrotalcite $[\mathrm{g} \mathrm{P}]^{-1}$. This treatment rate corresponds to HT containing $3.82 \% \mathrm{P}$ in the case of the $\mathrm{K}_{2} \mathrm{HPO}_{4}$ treatments, and spent litter treated at a rate of $74.3 \%$ of oven dry equivalent mass with HT.

Formulation materials were mixed together, water added to reach saturation, and incubated at $30{ }^{\circ} \mathrm{C}$ for 10 days prior to treatment of the pots. Following this incubation period, pot treatments were prepared individually. Each single pot treatment formulation was thoroughly mixed with sufficient soil for one pot, and the mass of soil packed into the pot.

Pasture seeds were germinated in trays, and planted into the soils subsequent to treatment. The initial planting was with digit grass (Digitaria eriantha cv. Premier), and replanted at 380 days with kikuyu grass (Pennisetum clandestinum cv. Whittet) to replenish plant stocks with a species observed to be more tolerant of the glasshouse conditions and to prevent disease issues.

Pots were maintained in a randomised and blocked row-column design on 12 benches. A total of 15 cuts were collected, at 4 to 5 week intervals. Dry matter production was determined following desiccation at $50{ }^{\circ} \mathrm{C}$, the samples were then ground and analysed for Total $\mathrm{N}$ (Dumas technique; Bremner, 1996) and Total P by Kjeldahl digest (Crowther et al., 1980).

Basal applications of $\mathrm{K}, \mathrm{Ca}, \mathrm{Mg}, \mathrm{S}, \mathrm{N}, \mathrm{Cu}, \mathrm{Zn}, \mathrm{Mn}, \mathrm{B}, \mathrm{Mo}$, and Fe were applied to all pots after plant establishment, and subsequent to each cut. Moisture contents were maintained around 70\% of measured field capacity via application of deionised water. Glasshouse temperature control was set at $25{ }^{\circ} \mathrm{C}$, and temperature loggers (http://www. hobodataloggers.com.au) were hung at $200 \mathrm{~mm}$ above pot height in the centre of each bench. Two pyranometers (http://www.soldata.dk/) and two relative humidity sensors (http://www.geminidataloggers. $\mathrm{com} /$ ) were also logged throughout the glasshouse trial.

Sandy soil pots were leached (between $28 / 6 / 2012$ and 2/08/2012) with a total of ten pore volumes of water ( 5 weekly events, each 2 pore volumes) to establish if the treatments had any effect in stabilising applied $\mathrm{P}$ in relation to leaching losses. Leachate samples were collected and analysed for molybdate reactive P. The same process was not conducted for the red clay due to the very high buffering capacity of that soil.

\subsection{Field trial}

A small plot $(1.5 \times 2 \mathrm{~m})$ field trial was established with pasture as the plant model (digit grass/sown with annual ryegrass in winter; $D$. eriantha/Lolium rigidum), with a treatment structure designed to investigate the effect of sorbers and spent litter versus conventional $\mathrm{N}$ and $\mathrm{P}$ sources (randomised treatment assignment to plots; Table 2). Spent litter contains both $\mathrm{N}$ and $\mathrm{P}$, so it was necessary to differentiate observations of these two nutrients through the use of basal fertiliser applications. Treatment formulations all underwent an identical wetting and incubation step to that described for the pot trial. Bentonite 
Table 2

Field trial layout at establishment.

\begin{tabular}{lll}
\hline $\begin{array}{l}\text { Treatments and } \\
\text { basal nutrients }\end{array}$ & Count & Description \\
\hline $\begin{array}{l}\text { Simultaneous N } \\
\text { and P rates }\end{array}$ & 4 & $\begin{array}{l}0 \mathrm{P}+0 \mathrm{~N} ; 24 \mathrm{P}+39 \mathrm{~N}, 48 \mathrm{P}+78 \mathrm{~N} ; 80 \mathrm{P}+131 \mathrm{~N} \\
\left(\mathrm{~kg} \mathrm{ha}^{-1}\right)\end{array}$ \\
$\begin{array}{l}\text { Nutrient forms } \\
\text { Sorber additions }\end{array}$ & 2 & $\begin{array}{l}\text { Spent litter or superphosphate + Urea } \\
\left. \pm \text { bentonite (3000 } \mathrm{kg} \mathrm{ha}^{-1}\right)+ \text { hydrotalcite (300 kg } \\
\left.\mathrm{ha}^{-1}\right) \\
\pm 131 \mathrm{~kg} \mathrm{~N} \mathrm{ha}^{-1}\end{array}$ \\
$\begin{array}{l}\text { Additional urea N } \\
\begin{array}{l}\text { Additional } \\
\text { superphosphate }\end{array}\end{array}$ & 2 & 2 \\
$\begin{array}{l}\text { P } \\
\text { Total plots }\end{array}$ & 64 & $\begin{array}{l}\text { Data analysis using only 2-way interactions (plus cut } \\
\text { number), where non-significant interactions were } \\
\text { pooled to increase the degrees of freedom of the } \\
\text { analysis }\end{array}$ \\
\hline
\end{tabular}

* Spent litter materials contain both $\mathrm{N}$ and $\mathrm{P}$ in a fixed ratio.

was included in the formulations to assist retention of $\mathrm{NH}_{4}^{+}$as described previously (Redding, 2011).

The site was located on the red clay soil and possessed $a \approx 1 \%$ slope. Each plot was located with the longest dimension in the direction of the slope, and was surrounded on each side by a buffer the same dimension as the plot. Solid-set irrigation (http://www.senninger.com/solid-set/ wobbler/; Xcel Wobbler size \#6, 100\% pattern overlap, $6 \mathrm{~m}$ irrigator spacing, delivering $250 \mathrm{l} \mathrm{h}^{-1}$ ) was installed across the site to ensure water uniformity and eliminate water limitations. Irrigation was scheduled twice weekly to meet pasture water demand. Individual plot allocation was completed randomly, with an approximately homogenous allocation across the site (relative to slope position and site dimensions).

Cuts were completed using a domestic push-style lawn mower with an attached catcher. Plots were subsequently raked, the mower cleaned, and collected material included in the sample. The entire sample was bagged and dried at $65{ }^{\circ} \mathrm{C}$ in a fan forced air flow, then weighed to determine dry matter content. These samples were then ground, subsampled via coning and quartering, and analysed as described for the pot trial.

Before and after the trial, soil in each plot was sampled ( 8 cores $40 \mathrm{~mm}$ in diameter, 0 to $75 \mathrm{~mm}$ depth, bulked together) and analysed as described for the pot trial. Three pasture cuts were completed on the trial plots before treatment applications to assess site uniformity, and to help remove any evident plot effects from the trial data (as an analysis covariate).

Basal applications of lime (2.5 $\left.\mathrm{t} \mathrm{ha}^{-1}\right)$ and gypsum $\left(1.25 \mathrm{tha} \mathrm{ha}^{-1}\right)$ were applied individually to each plot. Plots receiving additional $\mathrm{N}$ or $\mathrm{P}$ (Table 2), received these in the form of urea or superphosphate, respectively, individually weighed and applied to each plot. Treatments were applied into the pre-established $D$. eriantha $\mathrm{cv}$. Premier pasture by cutting 4 equidistant slots to $75 \mathrm{~mm}$ depth longitudinally across each plot. Pre-incubated formulations were inserted into the slots, and the remaining slot volume backfilled with the displaced soil.

Fifteen cuts were completed throughout the period from 23/01/2013 to $15 / 09 / 2014$, at intervals determined by estimated dry matter production. Maintenance nutrients were applied throughout the trial to optimise nutrient conditions. After each cut, the additional urea-N (Table 2) was re-applied to each plot, accompanied by (from August 2013, cut 5 , onwards) $144 \mathrm{~kg} \mathrm{ha}^{-1}$ of $\mathrm{K}_{2} \mathrm{SO}_{4}$. Plots that did not receive additional urea-N during trial establishment (Table 2) received a maintenance application of urea-N subsequent to each cut $\left(30 \mathrm{~kg} \mathrm{~N} \mathrm{ha}^{-1}\right)$, and for the final 3 cuts received $\mathrm{N}$ at the additional $\mathrm{N}$ rate $\left(131 \mathrm{~kg} \mathrm{~N} \mathrm{ha}^{-1}\right)$ to better identify residual $\mathrm{P}$ availability across all treatments.

\subsection{Conceptual investigation of on-going release potential}

The pasture species used in this trial were chosen, not to represent pasture production systems, but rather for their ability to enable multiple harvests (cuts) within each growing season. This capability enabled multiple extractions of the available nutrient ( $\mathrm{N}$ and $\mathrm{P}$ ), under substantially optimised growing conditions (e.g. irrigation) that tended to maximise uptake of the available nutrients. This pasture cut data therefore tends to represent maximum potential uptake.

For the pot trial, these maximum potential $\mathrm{P}$ uptake observations allow further interpretation of the data on a conceptual basis. Under commercial cropping conditions, nutrient captured by each crop is obtained not only from the current nutrient application, but also from residual nutrient from previous season applications (Helgason et al., 2007; Miller et al., 2009). We assumed residual nutrient release from the formulations was comparable to that demonstrated for the sandy soil in the pot trial, representing the final crop of 3 consecutive crops (using the data from 5 cuts per crop), summing residual and recently applied P:

$P_{\text {max }, \text { time } x}=\sum_{i=1}^{i=3} P_{x+(i-1) \times 5}$,

where $P_{\max , \text { time } x}$ represents maximum P uptake potential for a formulation at a time point during the third cropping cycle (time points represented by $x$; time 1 to time 5 ); $i$ represents the crop (crops 1 to current crop 3); and $P_{1}$ to $P_{15}$ represent the P removed with a single cut (15 cuts were collected during the trial).

\subsection{Statistics}

The row-column designed pot trial data was analysed for any spatial effects or covariance related to bench temperature data. Subsequently the dry matter and nutrient uptake data was analysed as a repeated measure ANOVA (Greenhouse-Geisser method) and REML using Genstat (GenStat, 2013).

Likewise, field trial data was analysed using an analysis of repeated measures ANOVA, using only 2-way interactions (plus cut number), where non-significant, the 3,4 and 5-way interactions were pooled to increase the degrees of freedom of the analysis. Plot nutrient status and uniformity cut data were investigated as possible data co-variates. Data analysis split the trial between the initial 12 cuts and the subsequent 3 cuts with the higher basal $\mathrm{N}$ rate.

The time-series nature of the data was taken into account by an analysis of variance of repeated measures (Rowell and Walters, 1976), via the AREPMEASURES procedure of GenStat (2013). This forms an approximate split-plot analysis of variance (split for time). The Greenhouse-Geisser epsilon estimates the degree of temporal autocorrelation, and adjusts the probability levels accordingly.

\section{Results}

\subsection{Pot trial}

Total P uptake and dry matter production from the inorganic $\mathrm{P}$ source exceeded that from spent litter or the equivalent treatments with added sorbent (Fig. 1). However, as the experiment proceeded $\mathrm{P}$ uptake from the inorganic P source decreased relative to the other sources, until these treatments were surpassed by sorbent treated inorganic sources and, in some cut/soil combinations, spent litter treatments (with or without sorbent). In particular, cumulate P uptake from the inorganic treatment after replanting (cut 13) in the sodosol soil was significantly less than that from all other sorbent and P source combinations $(P<0.05$; Fig. 2$)$.

Pooling all cuts, significant treatment effects were evident for each soil $(P<0.05$; Table 4$)$. In general, HT addition tended to decrease overall $\mathrm{P}$ uptake, but in combination with the Conv treatment in the sandy soil tended to increase uptake in the latter cuts (e.g. after re-planting). The nutrient source also influenced total P uptake and dry matter production, with SL tending to result in lower values than the Conv treatments overall. However, after re-planting the SL treatments tended to 


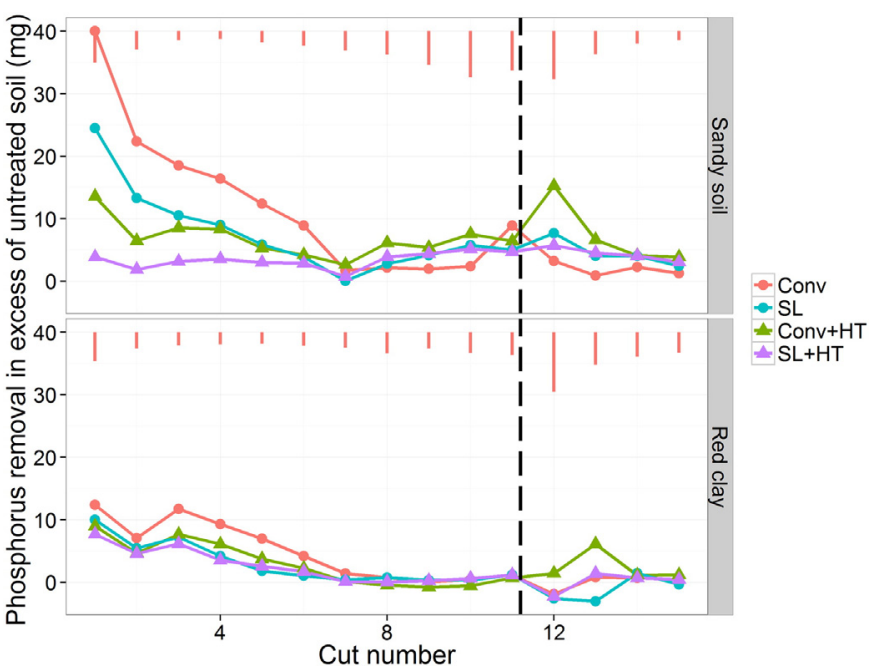

Fig. 1. Pot phosphorus uptake was significantly affected by the source of $P$, and the addition of sorbent. Bars indicate significance (LSD's, $P<0.05$ ), while the vertical dashed line indicates when the pots were replanted. Spent litter $=$ SL, hydrotalcite $=$ HT, conventional fertiliser $=$ Conv.

exceed the productivity of the Conv treatments in the sandy soil ( $\mathrm{P}$ uptake and dry matter production; $P<0.05$ ).

Addition of HT decreased molybdate reactive $\mathrm{P}$ leaching from all $\mathrm{P}$ sources from the sandy soil $(P<0.001$; Fig. 3$)$, to the same magnitude as soil with no $P$ addition (all treatment rates; LSD, $P<0.001$ ). Leaching losses of molybdate reactive $\mathrm{P}$ from the highest rate of $\mathrm{P}$ addition were significantly lower from the SL source than from the Conv source.

Phosphorus retained in the soils was increased via HT addition (Colwell P, both soils; red clay $1.4 \pm 0.6 \mathrm{mg} \mathrm{kg}^{-1}+\mathrm{HT}$; $<0.5 \mathrm{mg} \mathrm{kg}-1$ HT; sandy soil, $0.6 \pm 0.2 \mathrm{mg} \mathrm{kg}^{-1}+\mathrm{HT}$; $\left.<0.5 \mathrm{mg} \mathrm{kg}^{-1}-\mathrm{HT} ; \mathrm{P}<0.01\right)$.

\subsection{Field trial}

Dry matter production and nutrient uptake increased with additional $P$ and $N$ applications $(P<0.05)$. Phosphorus uptake from the SL source was equivalent to or greater than that from the Conv source $(P<0.05$; Fig. 4). Spent litter proved to be an equivalent source of $\mathrm{N}$ compared

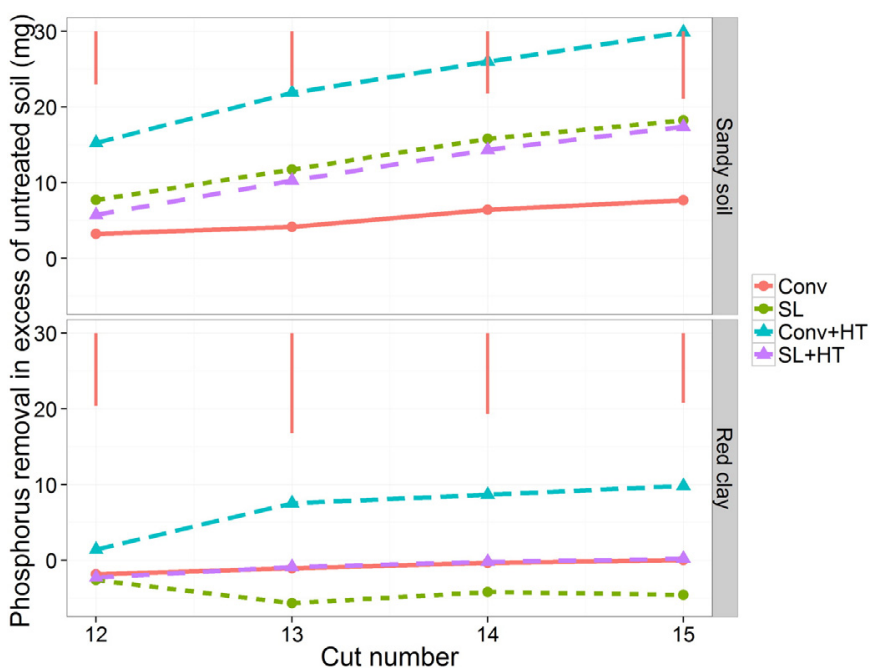

Fig. 2. Pot cumulative $P$ uptake following replanting (dashed vertical line, Fig. 1) was significantly affected by the source of $\mathrm{P}$, and the addition of sorbent. Analysis indicates significant differences for all time periods in each soil (REML ANOVA; LSD's plotted, $P<0.05)$. Spent litter $=$ SL, hydrotalcite $=H T$, conventional fertiliser $=$ Conv.

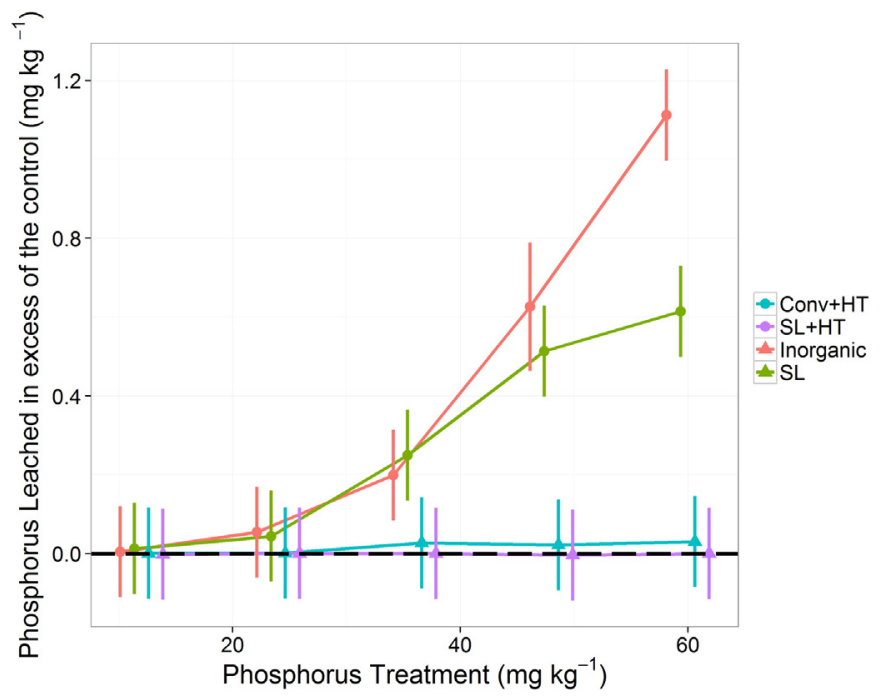

Fig. 3. Molybdate reactive P leached from the sandy soil pots with 10 pore volumes of water. Spent litter $=\mathrm{SL}$, hydrotalcite $=\mathrm{HT}$, conventional fertiliser $=$ Conv.

to the Conv source (SL $8.12 \mathrm{~g} \mathrm{~N} \mathrm{cut}^{-1}$, versus Conv $8.29 \mathrm{~g} \mathrm{~N} \mathrm{cut}^{-1}$, LSD at 0.05 level $=0.44 ; P>0.2$ ), though it resulted in significantly less mineral-N extractable from the soil at the end of the trial (SL 19.02 relative to Conv $22.63 \mathrm{mg} \mathrm{N} \mathrm{kg}^{-1}$; LSD at 0.05 level $=1.96$; $P=0.001)$.

Additions of bentonite and HT sorbents (at the decreased rate employed in this trial compared to the pot trial) had no significant influence on dry matter production or P uptake (no significant difference in total values; + sorbent, $0.959 \mathrm{~g} \mathrm{P}^{\mathrm{P} u t}{ }^{-1}$, versus - sorbent $0.919 \mathrm{~g}$ $\mathrm{P}_{\text {cut }}{ }^{-1}$, LSD at 0.05 level $=0.063 ; P>0.4$; no significant difference for any cut during the trial; $P<0.05)$. Similarly these additions did not modify N uptake (+ sorbent, $8.21 \mathrm{~g} \mathrm{~N}$ cut $^{-1}$, versus - sorbent $8.21 \mathrm{~g} \mathrm{~N}$ cut $^{-1}$, LSD at 0.05 level $=0.44 ; P>0.3$ ). Sorbent additions did not result in differences in the final trial soil samples for Colwell $\mathrm{P}$ (+ sorbent $17.66 \mathrm{mg} \mathrm{P} \mathrm{kg}^{-1}$ versus - sorbent $14.9 \mathrm{mg} \mathrm{P} \mathrm{kg}^{-1}$; LSD at 0.05 level $=4.00 ; P=0.169$ ), however, addition of the sorbent in combination with the no-basal $\mathrm{N}$ treatments retained more extractable mineral- $\mathrm{N}$ at the end of the trial $\left(20.02 \mathrm{mg} \mathrm{N} \mathrm{kg}^{-1}\right.$ relative to $16.84 \mathrm{mg} \mathrm{N} \mathrm{kg}^{-1}$; LSD at 0.05 level $\left.=2.77 ; P<0.05\right)$.

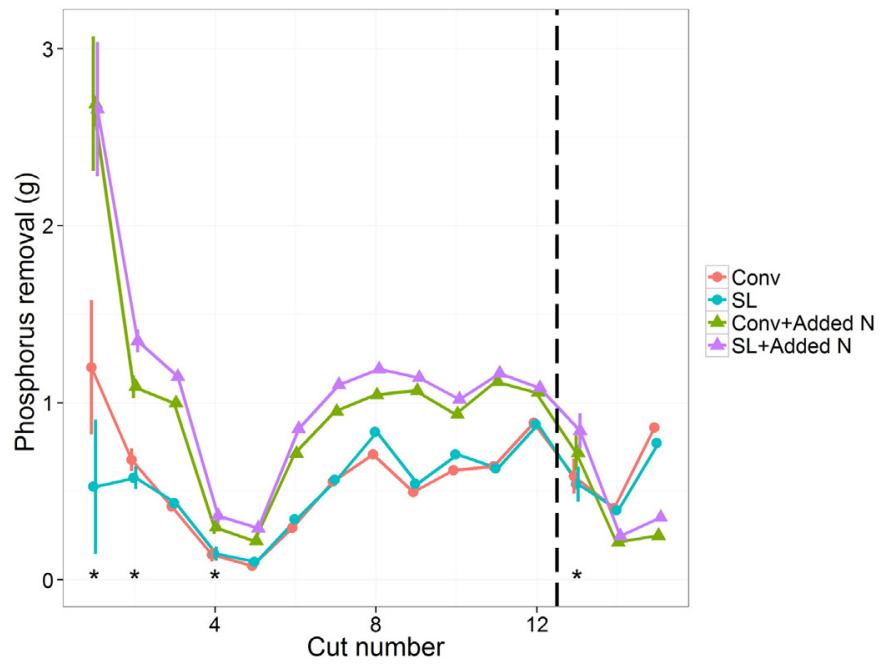

Fig. 4. Field trial $P$ removal, indicating the significant influence of nutrient source (significance indicated by ${ }^{*}$, LSD's plotted as error bars; $P<0.05$ ). The vertical dashed line indicates where additional $\mathrm{N}$ rates were homogenised across all treatments $\left(131 \mathrm{~kg} \mathrm{~N} \mathrm{ha}^{-1}\right)$. Spent litter $=\mathrm{SL}$, conventional fertiliser $=$ Conv. 


\section{Discussion}

\subsection{Pot trial}

Sorbent additions (HT) to the Conv treatment tended to defer nutrient availability. This was most evident for the sandy soil (Fig. 1), but was also evident for the red clay following re-planting (Figs. 1 and 2). The SL source of $\mathrm{P}$ also tended to defer $\mathrm{P}$ availability in the sandy soil, where $\mathrm{P}$ uptake following replanting exceeded nutrient supply from the Conv treatment (Fig. 2). This would be expected from previously published observations of the use of other manure forms as fertilisers (Helgason et al., 2007; Miller et al., 2009).

Overall, nutrient uptake from the Conv treatment exceeded that from treatments with HT or those that used the SL source. Given the effect of sorber addition or SL in deferring availability, this is an expected consequence. Over a longer time scale, a greater proportion of uptake from the HT and SL sources would likely occur. Indeed, it is evident from the sandy soil data that P delivery by the Conv treatments had declined to a very low level by cut 7 (Fig. 1), and began to be exceeded by the HT and SL treatments (Table 4, dry matter production cuts 13 to 16 from the Conv + HT and SL treatments both significantly exceed that from the Conv treatment, $P<0.05$; Figs. 1 and 2). At the completion of the experiment, Colwell P extractable from HT treated pots was significantly greater than from those without HT $(P<0.001)$.

Where water transport losses (leaching or run-off) are significant, there may also be advantages of HT application in terms of retained nutrients, in addition to decreased contamination of water resources with $P$. Leaching losses of molybdate reactive $P$ from the sandy soil were observed to be decreased to background levels via HT addition, and significantly decreased via the SL relative to the Conv source. Though total P losses were not measured in addition to molybdate reactive forms, these results are comparable to the total P run-off and leaching data following HT treatment reported previously (Redding, 2011).

The sandy soil provides much stronger treatment contrasts than were evident for the red clay, probably due to the much higher P buffering capacity of the red clay relative to the sandy soil (Table 3). Effectively, sorption sites comprising Fe and $\mathrm{Al}$ sesquioxides within the red clay are competing with HT sorption sites and plant uptake. However, significant P uptake differences were observed with HT treatment following replanting of the red clay (Fig. 2).

Addition of HT in combination with SL had a less clear effect on $P$ uptake, most likely because mineral-P represented a much smaller proportion of the $\mathrm{P}$ contained in this material than in the Conv treatment (much of the spent litter $\mathrm{P}$ was in the form of phytate; Table 1).

Table 3

Soil characteristics at commencement of the pot trial, reported on an oven dry basis. Electrical conductivity $=\mathrm{EC}$.

\begin{tabular}{llll}
\hline & Units & Sandy soil & Red clay \\
\hline $\mathrm{pH}$ & & $6.0 \pm 0.1$ & $6.0 \pm 0$ \\
$\mathrm{EC}$ & $\mathrm{dS} \mathrm{m}^{-1}$ & $0.03 \pm 0$ & 0.1 \\
Sand & $\%$ & $93.3 \pm 0.6$ & $24.7 \pm 0.6$ \\
Silt & $\%$ & $3 \pm 0$ & $21.7 \pm 1.5$ \\
Clay & $\%$ & $6 \pm 0$ & $53 \pm 1$ \\
Total N & $\%$ & $0.05 \pm 0.01$ & $0.197 \pm 0.003$ \\
$\mathrm{NO}_{3}^{-}-\mathrm{N}$ & $\mathrm{mg} \mathrm{kg}^{-1}$ & $3.73 \pm 0.26$ & $13.4 \pm 0.6$ \\
$\mathrm{NH}_{4}^{+}-\mathrm{N}$ & $\mathrm{mg} \mathrm{kg}$ & $12.7 \pm 0.8$ & $3.9 \pm 0.4$ \\
Total P & $\%$ & $0.01 \pm 0.00$ & $0.086 \pm 0.003$ \\
Phosphorus buffering index & & $16.1 \pm 3.9$ & $330 \pm 0$ \\
Bicarbonate P & $\mathrm{mg} \mathrm{kg}$ & $22.6 \pm 2.1$ \\
Total K & $\%$ & $0.077 \pm 0.004$ & $0.227 \pm 0.006$ \\
Organic C & $\%$ & $0.48 \pm 0.05$ & $2.42 \pm 0.05$ \\
Total C & $\%$ & $0.58 \pm 0.01$ & $2.90 \pm 0.04$ \\
\hline
\end{tabular}

\subsection{Field trial}

Though the soil at the site selected was a difficult one in which to prove P treatment effects (red clay soil has a high P buffering capacity; Table 3), nutrient contents were well within the responsive range. Trial data indicated a significant response to $\mathrm{P}$ and $\mathrm{N}$ applications (Dry matter production; $\mathrm{N}$ and $\mathrm{P}$ uptake; $P<0.05$ ).

Lower rates of HT addition were applied in the field trial than were applied in the pot trial, in an attempt to raise initial available P concentrations, allowing higher productivity (Fig. 2), while simultaneously attempting to continue deferring excess nutrient availability. The addition rate of HT was decreased from the pot trials rate $(26.2 \mathrm{~g}$ of hydrotalcite $\left[\mathrm{g} \mathrm{P}^{-1}\right.$ ) to the addition rate demonstrated to effectively eliminate P runoff losses in a previous study (3.75 and $7.5 \mathrm{~g}$ of hydrotalcite $[\mathrm{g} \mathrm{P}]^{-1}$; Redding, 2011). This rate allowed dry matter production and $\mathrm{P}$ uptake to reach the same magnitude as that from the Conv treatments (no significant difference in total values, $P>0.4$; no significant difference for any cut during the trial; $P<0.05$ ). However, the rate decrease also eliminated measureable evidence of deferral of $P$ availability, including in the final trial soil samples $(P=0.169)$.

Likewise there was no measured influence of the combination of bentonite $+\mathrm{HT}$ additions on $\mathrm{N}$ uptake during the trial. This is in contrast to a subsequent $\mathrm{N}$ trial at the same site where higher rates of bentonite addition delivered increased dry matter production (Pratt et al., 2015; a further manuscript in preparation).

However, the sorbent additions did increase the residual $\mathrm{KCl}$ extractable mineral- $\mathrm{N}$ in the soil by around $19 \%(P<0.05)$. This is probably related to the bentonite additions, which has a substantial cation exchange capacity (Table 1), which may tend to decrease water-borne transport of $\mathrm{N}$ and gaseous losses. Observations collected from related trials suggest that bentonite additions to SL decrease volatilisation losses during SL handling and storage (Redding, 2013). A related trial successfully used a vermiculite sorbent to decrease nitrous oxide emissions during fertiliser application of SL to the same soil (Hill et al., 2016).

The SL treatments performed largely equivalently to (or slightly better than) the Conv treatments in terms of $P$ uptake $(P<0.05$; Fig. 4$)$, and equivalently in terms of $\mathrm{N}$ uptake. This contrasts with the results of the $\mathrm{P}$ pot trial for this soil (Fig. 1). The red clay pots would have a number of effects on nutrient-plant interactions that would not occur in the field. First, nutrient losses would be less likely in the pot system, and so any advantage or disadvantage of SL versus Conv treatments with regard to nutrient retention may not be as fully expressed. Second, the root confinement that occurs in the pots may prevent observation of any root development contrast that could occur with SL versus Conv treatments in the field. Manure applications to soils are known to alter root development or increase root length density (Mosaddeghi et al., 2009).

The SL treatments resulted in a $19 \%$ decrease in residual extractable mineral-N at the end of the trial $(P=0.0001)$. It seems likely that this is related to an increase in $\mathrm{N}$ retained in organic manure-based forms for these treatments, rather than increased $\mathrm{N}$ losses from the SL treatments. Only about $15 \%$ of initial SL N was in the form of mineral-N (Table 1).

\subsection{Implications}

Development of fertiliser products capable of precise in-season nutrient supply (Chen et al., 2006, 2010) holds the promise of improving nutrient use efficiency and greater yields without increasing fertiliser use (Zhang et al., 2011). The ability to defer P supply demonstrated in the pot trial through the use of either SL or HT additions may be useful in achieving this goal, where crop uptake profiles often involve a greater nutrient requirement later in the season than at the beginning.

In common crop production practice, nutrient captured by each crop is obtained from the current nutrient application plus residual nutrient from previous applications (Helgason et al., 2007; Miller et al., 2009). A consideration of the likely effect of the formulations on on-going nutrient supply and release in crop production practice is possible, assuming 
Table 4

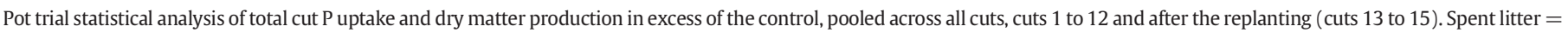
SL, hydrotalcite $=\mathrm{HT}$, conventional fertiliser $=$ Conv. For each treatment column, $n=12$.

\begin{tabular}{|c|c|c|c|c|c|c|}
\hline & Cuts & SL & $\mathrm{SL}+\mathrm{HT}$ & Conv & Conv + HT & $P$ \\
\hline \multicolumn{7}{|l|}{ Sandy soil } \\
\hline \multirow[t]{3}{*}{ P uptake (mg) } & All & $104 \pm 49$ & $58.2 \pm 28.1$ & $150 \pm 73.4$ & $107 \pm 55$ & n.s. \\
\hline & $1-12$ & $86.2 \pm 47.6$ & $39.5 \pm 26.4$ & $142 \pm 73$ & $78.3 \pm 42.5$ & n.s. \\
\hline & $13-16$ & $18.1 \pm 7.75_{\mathrm{ab}}$ & $19.0 \pm 12.5_{\mathrm{ab}}$ & $7.83 \pm 8.8_{b}$ & $28.7 \pm 17.4 \mathrm{a}$ & $<0.01$ \\
\hline \multirow[t]{3}{*}{ Dry matter (g) } & All & $109 \pm 42$ & $63.5 \pm 28.5$ & $165 \pm 68$ & $110 \pm 47$ & n.s. \\
\hline & $1-12$ & $91.9 \pm 42.3_{\mathrm{b}}$ & $49.5 \pm 27.1_{c}$ & $158 \pm 68 \mathrm{a}$ & $88.7 \pm 37.9_{b}$ & $<0.05$ \\
\hline & $13-16$ & $16.3 \pm 6.4 \mathrm{a}$ & $13.8 \pm 8.9_{\mathrm{ab}}$ & $7.95 \pm 7.02_{\mathrm{b}}$ & $21.1 \pm 11.5 \mathrm{a}$ & $<0.05$ \\
\hline \multicolumn{7}{|l|}{ Red clay } \\
\hline \multirow[t]{3}{*}{ P uptake (mg) } & All & $29.1 \pm 25.0_{\mathrm{b}}$ & $28.9 \pm 21.5_{\mathrm{b}}$ & $56.6 \pm 38.8 \mathrm{a}$ & $42.7 \pm 17.5_{\mathrm{ab}}$ & $<0.05$ \\
\hline & $1-12$ & $34.3 \pm 26.5_{b}$ & $28.1 \pm 21.4_{\mathrm{b}}$ & $55.9 \pm 33.4_{a}$ & $33.0 \pm 13.0_{\mathrm{b}}$ & $<0.05$ \\
\hline & $13-16$ & $-4.6 \pm 8.7^{*}$ & $0.3 \pm 6.7$ & $0.8 \pm 9.6$ & $9.8 \pm 7.9$ & n.s \\
\hline \multirow[t]{3}{*}{ Dry matter (g) } & All & $26.2 \pm 24.9$ & $22.2 \pm 18.0$ & $44.7 \pm 26.1$ & $30.2 \pm 14.0$ & n.s. \\
\hline & $1-12$ & $29.1 \pm 27.0$ & $22.0 \pm 19.0$ & $44.6 \pm 22.4$ & $24.6 \pm 12.9$ & n.s. \\
\hline & $13-16$ & $-1.98 \pm 4.36^{*}$ & $-0.02 \pm 3.55^{*}$ & $-1.15 \pm 6.31^{*}$ & $5.33 \pm 5.25$ & n.s. \\
\hline
\end{tabular}

Treatments with common letters are not significantly different.

* Negative values suggest production was exceeded by the controls, though none of these deficits are significant.

that the pasture cut data tends to represent maximum potential uptake. Eq. (1) was applied to the \pm HT treatments (Fig. 5, panel A) and Conv versus SL P sources (Fig. 5, panel B), indicating significant effects of HT addition and the SL source in deferring nutrient availability in the third season of production and nutrient application.
These Eq. (1) outputs were then used to formulate curves for Conv, Conv $+\mathrm{HT}$, and SL $+\mathrm{HT}$, where each curve was rescaled to represent equal cumulative release (based integration of area under the curve), and a conceptual diagram prepared (Fig. 5, panel C). This figure suggests that following three successive fertiliser applications for three crops, the

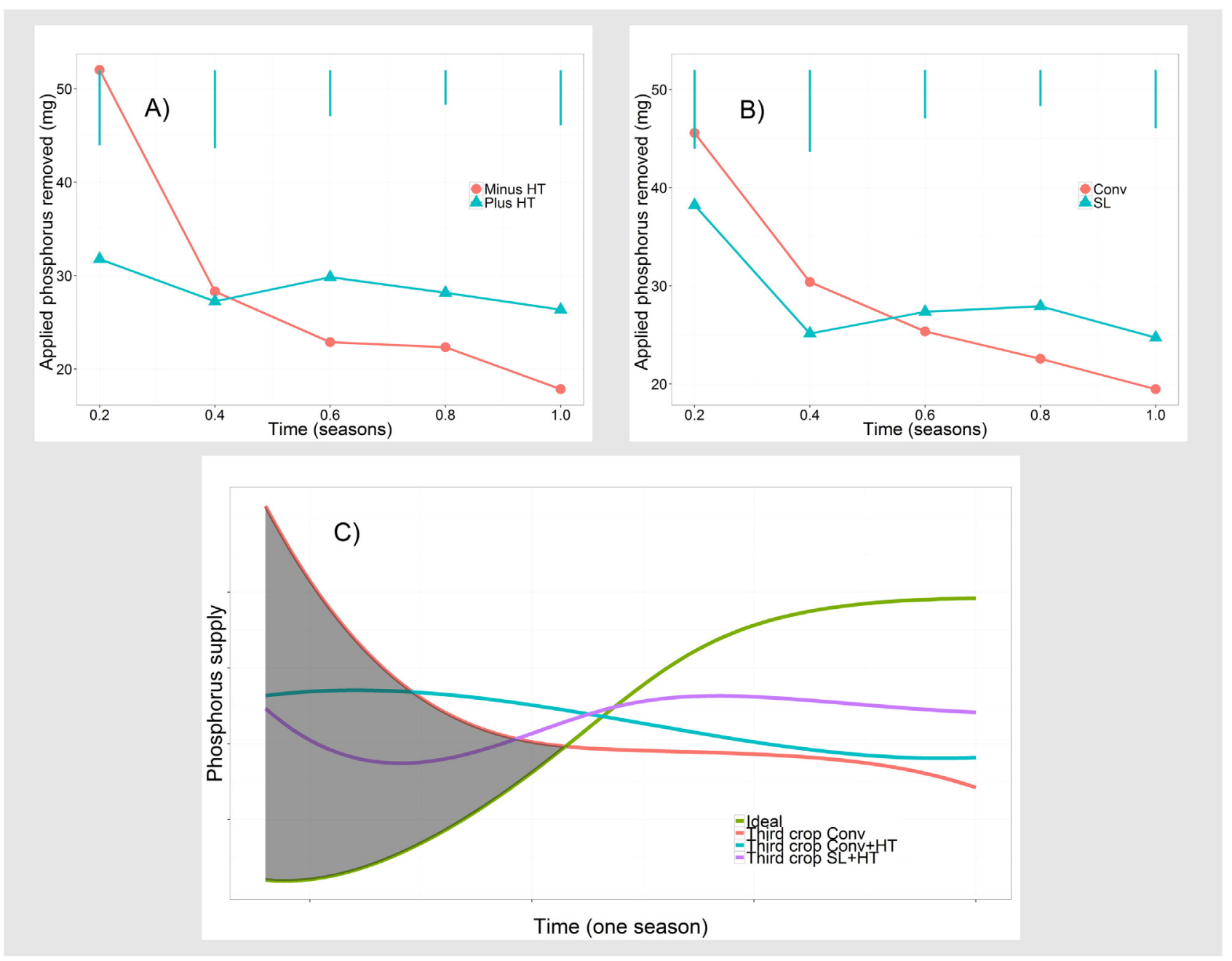

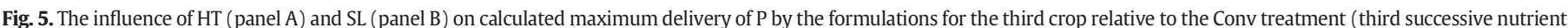

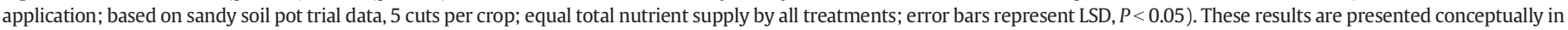

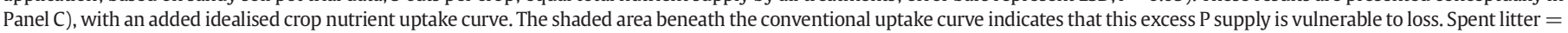
SL, hydrotalcite $=\mathrm{HT}$, conventional fertiliser $=$ Conv. 
HT and SL forms may better match the ideal nutrient uptake profiles of many crops relative to conventional fertiliser treatments (based on sandy soil pot trial data, 5 cuts per crop). While the excess initial nutrient availability associated with the Conv treatment is vulnerable to losses (Fig. 5, panel C, shaded region), this is not the case where HT is used as an additive.

While the plant uptake data from the field does not indicate any evidence of $\mathrm{N}$ availability deferral, the soil data does. It is likely that sorbent (bentonite) additions to the spent litter resulted in an increase of $19 \%$ in residual mineral-N being carried over beyond the trial, with no decrease in productivity during the trial. This increase is probably the result of lower $\mathrm{N}$ losses via a variety of paths. The use of SL as a source of $\mathrm{N}$ resulted in decreased extractable mineral- $\mathrm{N}$ at the end of the trial. While it is likely that this reflects the retention of $\mathrm{N}$ in organic forms, this has not been established. The differences in mineral- $\mathrm{N}$ between the Conv and SL treatments ( $3.6 \mathrm{mg} \mathrm{P} \mathrm{kg}^{-1}$ ) are probably beyond the sensitivity of available total $\mathrm{N}$ techniques to resolve.

The combination of our field trial results, our pot trial leaching data, and the observations from our previous (Hill et al., 2016; Pratt et al., 2015; Redding, 2011, 2013; decreased $\mathrm{N}_{2} \mathrm{O}$ and $\mathrm{NH}_{4}^{+}$emission, and decreased $\mathrm{P}$ leaching and runoff losses with ion exchanger additions) and other researchers' studies (Aghaalikhani et al., 2012; Ding et al., 2010; Gholamhoseini et al., 2013; Singh et al., 2010; establishing decreased $\mathrm{N}$ leaching losses with ion exchanger additions) indicate that it is possible to match the productivity of conventional $\mathrm{N}$ and $\mathrm{P}$ sources, and achieve decreased potential for nutrient losses via the use of manure materials and ion exchange sorbents.

\subsection{Cost benefit}

It is evident that there can be a substantial cost benefit to using spent litter as a source of $\mathrm{N}, \mathrm{P}$, and $\mathrm{K}$ for plant production relative to conventional fertilisers (e.g. estimates in Table 5; based on Australian fertiliser price data, and poultry industry statistics; Runge et al., 2007). To prevent excess $P$ application, application rates were based on the P content of the spent litter, and the supplemental conventional fertiliser applied matched conventional $\mathrm{N}$ application rates. A key assumption of these estimates is that spent litter $\mathrm{N}$ and $\mathrm{P}$ availability are equivalent to conventional fertiliser sources. This is supported by the field trial

\section{Table 5}

Estimated cost benefit (without transport costs) and assumptions of a conventional fertiliser scenario versus a spent litter scenario. Additional assumptions include that the spent litter $\mathrm{N}, \mathrm{P}$, and $\mathrm{K}$ are as available as conventional fertiliser forms of these nutrients. Increasing transport radii will decrease the spent litter scenario cost difference (radius used for calculation, $0 \mathrm{~km}$ ).

\begin{tabular}{|c|c|c|c|}
\hline Estimated parameters & US $\$ / \mathrm{kg}$ & $\begin{array}{l}\mathrm{kg} \\
\mathrm{ha}^{-1}\end{array}$ & US \$/ha \\
\hline \multicolumn{4}{|l|}{ Conventional scenario } \\
\hline Conventional $\mathrm{N}$ & 0.82 & 200 & 164.89 \\
\hline Conventional P & 2.47 & 48 & 118.72 \\
\hline Conventional K & 1.02 & 66 & 67.51 \\
\hline Fertiliser spreading & & & 2.29 \\
\hline Conventional scenario & & & 353.40 \\
\hline \multicolumn{4}{|l|}{ Spent litter scenario } \\
\hline Spent litter application rate & & 2490 & \\
\hline cost of obtaining spent litter & $\begin{array}{l}-0.012 \text { to } \\
0.084\end{array}$ & & $\begin{array}{l}-29.90 \text { to } \\
209.16\end{array}$ \\
\hline Spent litter N & & 77 & \\
\hline Spent Litter P & & 48 & \\
\hline Spent Litter K & & 70 & \\
\hline Supplemental N & & 123 & 101.73 \\
\hline Spent litter application & & & 4.58 \\
\hline Supplemental N spreading & & & 2.29 \\
\hline $\begin{array}{l}\text { Additional tillage and } \\
\text { management }\end{array}$ & & & 9.92 \\
\hline Spent litter scenario & & & 88.63 to 327.69 \\
\hline Cost difference & & & 25.71 to 264.77 \\
\hline
\end{tabular}

observations. Given that spent litter $\mathrm{K}$ is largely in the exchangeable form (Table 1), fertiliser equivalence has also been assumed in the case of this nutrient. The benefits of substitution will decrease as the transport radius from the poultry farm increases, given that spent litter transport will be more expensive than conventional fertiliser to transport.

Our data suggests that a cost benefit is unlikely to be derived from either of the clay treatments unless the environmental benefits of fertiliser modification with these treatments is remunerated, or where longer term cost benefits are established and included in considerations. A cost benefit analysis (and Life Cycle Analysis) has been conducted for low rate bentonite addition ( $300 \mathrm{~kg} \mathrm{ha}^{-1}$ ) to manure materials in a related trial (Pratt et al., in review). In that study, where carbon prices and greenhouse gas emissions were taken into account, the economic viability of low rate clay additions to manure was dependent on achieving decreased greenhouse gas emissions (as established in the study via decreased nitrous oxide emissions, and assuming; >U.S. \$23/t carbon price) and at least a $10 \%$ increase in agronomic productivity. Therefore, the high application rate of bentonite applied in the field trial (3000 $\mathrm{kg} \mathrm{ha}^{-1}$ ), without any established yield increase, is unlikely to be economically viable without some valuation of improved environmental performance. This is due to the estimated clay acquisition and application costs of around U.S. $\$ 118 \mathrm{ha}^{-1}$ (assuming a clay price of U.S. $\$ 38 \mathrm{t}^{-1}$, field application cost of U.S. $\$ 4.58 \mathrm{t}^{-1}$ ).

Similarly, the addition of HT (at $300 \mathrm{~kg} \mathrm{ha}^{-1}$ ) did not establish an agronomic benefit during the course of the studies, though equivalence was achieved in the field trial. The evidence of deferred P availability suggests that in the longer term, benefits may emerge. However, current data suggests that without remuneration for the environmental benefits of this practice, there would be no cost benefit to these applications of HT (previously valued at U.S. $\$ 1000 \mathrm{t}^{-1}$, Gillman, 2006).

\section{Conclusions}

In the pot trial, sorbent additions (26.2 $\mathrm{g}$ of hydrotalcite $[\mathrm{g} \mathrm{P}]^{-1}$ ) to the Conv treatment tended to defer $\mathrm{P}$ availability. The SL source of $\mathrm{P}$ also tended to defer P availability in the sandy soil. In this soil, P delivery by the Conv treatments had declined rapidly, and began to be exceeded by the HT and SL treatments, and greater Colwell P was extractable from + HT treated pots at the end of the trial than from those that did not have this additive. Leaching losses of molybdate reactive $P$ from the sandy soil were observed to be decreased to background levels via HT addition, and significantly decreased via the SL relative to the Conv source.

Lower rates of HT addition applied in the clay soil field trial ( 3.75 and $7.5 \mathrm{~g}$ of hydrotalcite $[\mathrm{g} \mathrm{P}]^{-1}$; rates previously demonstrated to eliminate $P$ leaching and significantly decrease runoff loss potential) allowed dry matter production and $\mathrm{P}$ uptake to reach the same magnitude as that from the Conv treatments (no significant difference for any cut during the trial; $P<0.05$ ). However, the HT rate decrease also eliminated measureable evidence of deferral of $P$ availability, including in the final trial soil samples $(P=0.169)$.

The combination of bentonite + HT additions $\left(3000 \mathrm{~kg} \mathrm{ha}^{-1}\right.$ and $300 \mathrm{~kg} \mathrm{ha}^{-1}$, respectively) increased soil residual mineral-N at the end of the field trial by $19 \%(P<0.05)$. The field trial SL treatments performed largely equivalently to (or slightly better than) the Conv treatments in terms of P uptake $(P<0.05)$, and equivalently in terms of $\mathrm{N}$ uptake. Less residual mineral-N (19\%) was present in the SL treated soils than in the Conv treated soils at the completion of the trial.

The sandy soil pot trial data suggests that following three successive fertiliser applications for three crops, the HT + SL and HT + Conv forms may better match the ideal nutrient uptake profiles of many crops relative to conventional fertiliser treatments.

The combination of our field trial results, our pot trial leaching data, and the observations from our other studies indicate that it is possible to match the productivity of conventional $\mathrm{N}$ and $\mathrm{P}$ sources, and achieve 
decreased potential for nutrient losses via the use of manure materials and ion exchange sorbents.

\section{Acknowledgements}

This research was conducted within the Poultry CRC, established and supported under the Australian Government's Cooperative Research Centres Program, and co-funded by Queensland State Government. I'd like to thank Mr. Jarl Devereux for his contributions during the conduct of these experiments; Dr. Gavin Gillman for his assistance in the design and establishment of this research; Dr. Chris Pratt for his assistance in preparation of the manuscript; and Mr. David Mayer for biometric assistance. Authors are listed in order of contribution.

\section{References}

Adeli, A., Tewolde, H., Rowe, D.E., Sistani, K.R., 2011. Continuous and residual effects of broiler litter application to cotton on soil properties. Soil Sci. 176, 668-675. http:// dx.doi.org/10.1097/SS.0b013e3182343507.

Aghaalikhani, M., Gholamhoseini, M., Dolatabadian, A., Khodaei-Joghan, A., Sadat Asilan, K., 2012. Zeolite influences on nitrate leaching, nitrogen-use efficiency, yield and yield components of canola in sandy soil. Arch. Agron. Soil Sci. 58, 1149-1121.

Archontoulis, S.V., Miguez, F.E., Moore, K.J., 2014. Evaluating APSIM maize, soil water, soil nitrogen, manure, and soil temperature modules in the Midwestern United States. Agron. J. 106, 1025-1040. http://dx.doi.org/10.2134/agronj2013.0421.

Bar-Tal, A., Yermiyahu, U., Beraud, J., Keinan, M., Rosenberg, R., Zohar, D., Rosen, V., Fine, P. 2004. Nitrogen, phosphorus, and potassium uptake by wheat and their distribution in soil following successive, annual compost applications. J. Environ. Qual. 33 , $1855-1865$.

Beraud, J. Fine, P. Yermiyahu, U, Keinan, M, Rosenberg R, Hadas, A., Bar-Tal, A., 2005. Modeling carbon and nitrogen transformations for adjustment of compost application with nitrogen uptake by wheat. J. Environ. Qual. 34, 664-675

Bolland, M.D.A., Gilkes, R.J., 1998. The chemistry and agronomic effectiveness of phosphate fertilizers. J. Crop. Prod. 1, 139-163.

Bremner, J.M., 1996. Nitrogen - total. In: Sparks, D.L., Page, A.L., Helmke, P.A., Loeppert R.H., Soltanpour, P.N., Tabatabai, M.A., Johnston, C.T., Sumner, M.E. (Eds.), Methods of Soil Analysis. Soil Science Society of America Inc., Madison, pp. 1085-1121.

Chardon, W., Oenema, O., del Castilho, P., Vriesema, R., Japenga, J., Blaauw, D., 1997. Organic phosphorus in solutions and leachates from soils treated with animal slurries. J. Environ. Qual. 26, 372-378.

Chen, X., Zhang, F., Römheld, V., Horlacher, D., Schulz, R., Böning-Zilkens, M., Wang, P., Claupein, W., 2006. Synchronizing N supply from soil and fertilizer and N demand of winter wheat by an improved Nmin method. Nutr. Cycl. Agroecosyst. 74, 91-98. http://dx.doi.org/10.1007/s10705-005-1701-9.

Chen, X.P., Zhang, F.S., Cui, Z.L., Li, F., Li, J.L., 2010. Optimizing soil nitrogen supply in the root zone to improve maize management all rights reserved. Soil Sci. Soc. Am. J. 74, 1367-1373.

Crosland, A.R., Zhao, F.J., McGrath, S.P., Lane, P.W., 1995. Comparison of aqua-regia digestion with sodium-carbonate fusion for the determination of total phosphorus in soils by inductively-coupled plasma-atomic emission-spectroscopy (ICP). Commun. Soil Sci. Plant Anal. 26, 1357-1368.

Crowther, J., Wright, B., Wright, W., 1980. Semiautomated determination of total phosphorus and total Kjeldahl nitrogen in surface waters. Anal. Chim. Acta 119 313-321. http://dx.doi.org/10.1016/S0003-2670(01)93632-3.

Cui, Z., Zhang, F., Chen, X., Dou, Z., Li, J., 2010. In-season nitrogen management strategy for winter wheat: maximizing yields, minimizing environmental impact in an over-fertilization context. Field Crop Res. 116, 140-146. http://dx.doi.org/10.1016/j.fcr.2009 12.004

Danaher, M., Jordan, K., 2013. Identification of existing and emerging chemical residue contamination concerns in milk. Ir. J. Agric. Food Res. 52.

Dave, A., Mehta, M., Aminabhavi, T., Kulkarni, A., Soppimath, K., 1999. A review on controlled release of nitrogen fertilizers through polymeric membrane devices. PolymPlast. Technol. Eng. 38, 675-711. http://dx.doi.org/10.1080/03602559909351607.

David, M.B., Gentry, L.E., 2000. Anthropogenic inputs of nitrogen and phosphorus and riverine export for Illinois, USA. J. Environ. Qual. 29, 494-508.

Di, H.J., Cameron, K.C., 2002. Nitrate leaching in temperate agroecosystems: sources, factors and mitigating strategies. Nutr. Cycl. Agroecosyst. 64, 237-256. http://dx.doi.org/ 10.1023/A:1021471531188.

Ding, Y., Liu, Y.-X., Wu, W.-X., Shi, D.-Z., Yang, M., Zhong, Z.-K., 2010. Evaluation of biochar effects on nitrogen retention and leaching in multi-layered soil columns. Water Air Soil Pollut. 213, 47-55

Drinkwater, L.E., Snapp, S.S. 2007. Nutrients in agroecosystems: rethinking the management paradigm. Adv. Agron. 92, 163-186.

Edmeades, D.C., 2003. The long-term effects of manures and fertilisers on soil productivity and quality: a review. Nutr. Cycl. Agroecosyst. 66, 165-180. http://dx.doi.org/10. 1023/A:1023999816690.

Ellis, C., 1907. Fertilizer and process for making the same. 847, 749.

Galloway, J.N., Cowling, E.B., 2002. Reactive nitrogen and the world: 200 years of change Ambio 31, 64-71.

GenStat, 2013. GenStat for Windows, Release 15.3. VSN International Ltd., Oxford.
Gholamhoseini, M., Ghalavand, A., Khodaei-Joghan, A., Dolatabadian, A., Zakikhani, H., Farmanbar, E., 2013. Zeolite-amended cattle manure effects on sunflower yield, seed quality, water use efficiency and nutrient leaching. Soil Tillage Res. 126, 193-202. http://dx.doi.org/10.1016/j.still.2012.08.002.

Gillman, G.P., 2006. Converting feedlot waste to fertilizer using charged clays: environmental and economic benefits. Environ. Qual. Manag. 16, 73-80.

Gillman, G.P., 2011. Charged clays: an environmental solution. Appl. Clay Sci. 53, 361-365.

Gillman, G., Noble, A., 2005. Environmentally manageable fertilizers: a new approach. Environ. Qual. Manag. 15, 59-70.

Halvorson, A.D., Snyder, C.S., Blaylock, A.D., Del Grosso, S.J., 2014. Enhanced-efficiency nitrogen fertilizers: potential role in nitrous oxide emission mitigation. Agron. J. 106, $715-722$

Helgason, B.L., Larney, F.J., Janzen, H.H., Olson, B.M., 2007. Nitrogen dynamics in soil amended with composted cattle manure. Can. J. Soil Sci. 87, 43-50. http://dx.doi. org/10.4141/S06-023.

Hill, J., Redding, M.R., Pratt, C., 2016. A novel and effective technology for mitigating nitrous oxide emissions from land-applied manures. Anim. Prod. Sci. 56, 362-369.

Irigoyen, I., Muro, J., Azpilikueta, M., Aparicio-Tejo, P., Lamsfus, C., 2003. Ammonium oxidation kinetics in the presence of nitrification inhibitors DCD and DMPP at various temperatures. Soil Res. 41, 1177-1183.

Isbell, R.F., 2002. The Australian Soil Classification, Australian Soil and Land Survey Handbook. CSIRO Publishing, Collingwood, Victoria, Australia.

Kihanda, F.M., Warren, G.P., Micheni, A.N., 2005. Effects of manure and fertilizer on grain yield, soil carbon and phosphorus in a 13-year field trial in semi-arid Kenya. Exp. Agric. 41, 389-412.

Lammel, J., 2005. Cost of the different options available to the farmers: Current situation and prospects. IFA International Workshop on Enhanced-Efficiency Fertilizers, Frankfurt. International Fertilizer Industry Association, Paris, France.

Latta, M., Eskin, M., 1980. A simple and rapid colorimetric method for phytate determination. J. Agric. Food Chem. 28, 1313-1315. http://dx.doi.org/10.1021/jf60232a049.

Li, Z., Zhang, Y., Li, Y., 2013. Zeolite as slow release fertilizer on spinach yields and quality in a greenhouse test. J. Plant Nutr. 36, 1496-1505. http://dx.doi.org/10.1080/ 01904167.2013 .790429

Miller, J.J., Beasley, B.W., Drury, C.F., Zebarth, B.J., 2009. Barley yield and nutrient uptake for soil amended with fresh and composted cattle manure. Agron. J. 101, 1047-1059.

Mosaddeghi, M.R., Mahboubi, A.A., Safadoust, A, 2009. Short-term effects of tillage and manure on some soil physical properties and maize root growth in a sandy loam soil in western Iran. Soil Tillage Res. 104, 173-179. http://dx.doi.org/10.1016/j.still. 2008.10.011.

Nasholm, T., Kielland, K., Ganeteg, U., 2009. Uptake of organic nitrogen by plants. New Phytol. 182, 31-48. http://dx.doi.org/10.1111/j.1469-8137.2008.02751.x.

Paungfoo-Lonhienne, C., Lonhienne, T.G.A., Rentsch, D., Robinson, N., Christie, M., Webb, R.I., Gamage, H.K., Carroll, B.J., Schenk, P.M., Schmidt, S., 2008. Plants can use protein as a nitrogen source without assistance from other organisms. Proc. Natl. Acad. Sci. U. S. A. 105, 4524-4529. http://dx.doi.org/10.1073/pnas.0712078105.

Paungfoo-Lonhienne, C., Visser, J., Lonhienne, T.A., Schmidt, S., 2012. Past, present and future of organic nutrients. Plant Soil 359, 1-18. http://dx doi.org/10.1007/s11104-0121357-6.

Perego, A., Basile, A., Bonfante, A., De Mascellis, R., Terribile, F., Brenna, S., Acutis, M., 2012. Nitrate leaching under maize cropping systems in Po Valley (Italy). Agric. Ecosyst. Environ. 147, 57-65. http://dx.doi.org/10.1016/j.agee.2011.06.014.

Pratt, C., Redding, M., Hill, J., 2015. Application of sorbers to mitigate greenhouse gas emissions from land-applied pig litter. Manipulating Pig Production XVPresented at the Manipulating Pig Production XV. Australasian Pig Science Association, Grand Hyatt, Melbourne, Australia.

Pratt, C., Hill, J., Brown, G., Wiedemann, S., Redding, M., 2016. Tightening nitrogen cycling in agronomic settings using high cation exchange capacity clays. Proc. Natl. Acad. Sci. U. S. A. (in review)

Queensland Government, 2015. Reef water quality protection plan [WWW Document]. URL http://www.reefplan.qld.gov.au/ (accessed 4.19.15).

Rasouli, S., Whalen, J.K., Madramootoo, C.A., 2014. Review: reducing residual soil nitrogen losses from agroecosystems for surface water protection in Quebec and Ontario, Canada: best management practices, policies and perspectives. Can. J. Soil Sci. 94, 109-127. http://dx.doi.org/10.4141/CJSS2013-015.

Rayment, G.E., Lyons, D.J., 2010. Soil Chemical Methods - Australasia.

Redding, M.R., 2011. Bentonites and layered double hydroxides can decrease nutrient losses from spent poultry litter. Appl. Clay Sci. 52, 20-26. http://dx.doi.org/10.1016/ j.clay.2011.01.016.

Redding, M.R., 2013. Bentonite can decrease ammonia volatilisation losses from poultry litter: laboratory studies. Anim. Prod. Sci. http://dx.doi.org/10.1071/AN12367.

Rowell, J.G., Walters, D.E., 1976. Analysing data with repeated observations on each experimental unit. J. Agric. Sci. 87, 423-432. http://dx.doi.org/10.1017/ S0021859600027763.

Runge, G.A., Blackall, P.J., Casey, K.D., 2007. Chicken Litter: Issues Associated with Sourcing and Use. Rural Industries Research and Development Corporation, Kingston ACT, Canberra, Australia

Ruser, R., Schulz, R., 2015. The effect of nitrification inhibitors on the nitrous oxide $\left(\mathrm{N}_{2} \mathrm{O}\right)$ release from agricultural soils-a review. J. Plant Nutr. Soil Sci. 178, 171-188. http:// dx.doi.org/10.1002/jpln.201400251.

Schmidt, S., Raven, J.A., Paungfoo-Lonhienne, C., 2013. The mixotrophic nature of photosynthetic plants. Funct. Plant Biol. 40, 425-438, http://dx.doi.org/10.1071/FP13061.

Shaviv, A., 2001. Advances in controlled-release fertilizers. Advances in Agronomy. Academic Press, pp. 1-49.

Singh, B.P., Hatton, B.J., Singh, B., Cowie, A.L., Kathuria, A., 2010. Influence of Biochars on nitrous oxide emission and nitrogen leaching from two contrasting soils. J. Environ. Qual. 39, 1224. http://dx.doi.org/10.2134/jeq2009.0138. 
Smith, K.A., Chalmers, A.G., Chambers, B.J., Christie, P., 1998. Organic manure phosphorus accumulation, mobility and management. Soil Use Manag. 14, 154-159. http://dx.doi. org/10.1111/j.1475-2743.1998.tb00634.x.

Smith, D.R., Owens, P.R., Leytem, A.B., Warnemuende, E.A., 2007. Nutrient losses from manure and fertilizer applications as impacted by time to first runoff event. Environ. Pollut. 147, 131-137. http://dx.doi.org/10.1016/j.envpol.2006.08.021.

Soil Survey Staff, 1998. Keys to Soil Taxonomy. eighth ed. United Sates Department of Agriculture, Natural Resource Conservation Service, Washington, D.C.

Timilsena, Y.P., Adhikari, R., Casey, P., Muster, T., Gill, H., Adhikari, B., 2015. Enhanced efficiency fertilisers: a review of formulation and nutrient release patterns. J. Sci. Food Agric. 95, 1131-1142. http://dx.doi.org/10.1002/jsfa.6812.

Trenkel, M.E., 2010. Slow- and Controlled-Release and Stabilized Fertilizers: An Option for Enhancing Nutrient Use Efficiency in Agriculture. IFA, International Fertilizer Industry Association.
Van der Molen, D.T., Breeuwsma, A., Boers, P.C.M., 1998. Agricultural nutrient losses to surface water in The Netherlands: impact, strategies, and perspectives. J. Environ. Qual. 27, 4.

Walkley, A., Black, I., 1934. An examination of the Degtjareff method for determining soil organic matter and a proposed modification of the chromic acid titration method. Soil Sci. 37, 29-38.

Zhang, F., Cui, Z., Fan, M., Zhang, W., Chen, X., Jiang, R., 2011. Integrated soil-crop system management: reducing environmental risk while increasing crop productivity and improving nutrient use efficiency in China. J. Environ. Qual. 40, 1051-1057.

Zhang, F., Chen, X., Vitousek, P., 2013. An experiment for the world. Nature 497, 33-35. 